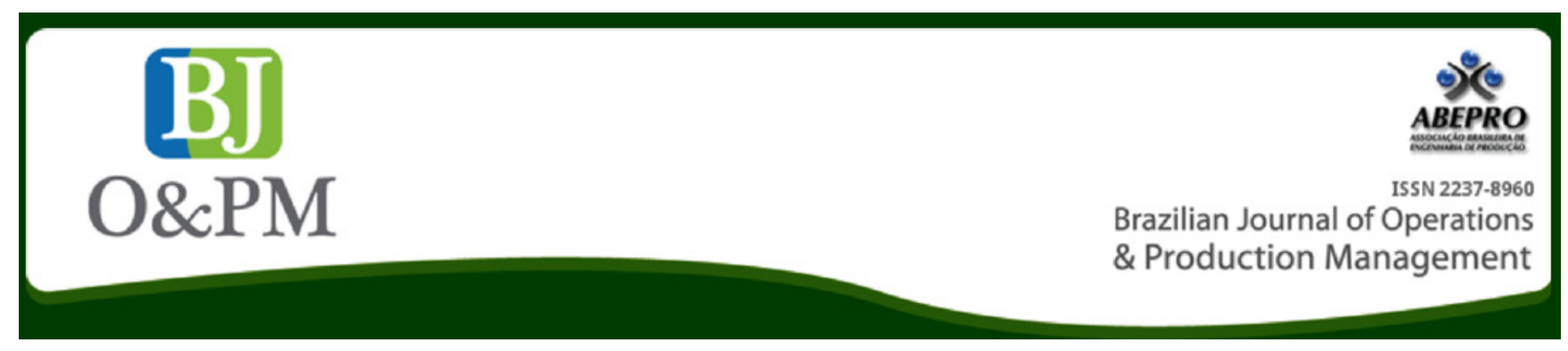

\title{
COMPARATIVE STUDY OF BRAZILIAN PUBLIC CONTAINER TERMINALS: TECHNICAL EFFICIENCY RANKING AND FORECASTS FOR 2052
}

\author{
Ilton Curty Leal Junior; ; Vanessa de Almeida Guimarães ${ }^{\mathrm{b}}$; Ricardo da Silva Guabirobaa; Renata Ribeiro Fonseca ${ }^{\mathrm{c}}$ \\ ${ }^{\text {a }}$ Fluminense Federal University (UFF) - Niterói, RJ, Brazil \\ ${ }^{b}$ Federal Center of Technological Education Celso Suckow da Fonseca (CEFET) - Rio de Janeiro, RJ, Brazil \\ c Instruction Center Almirante Alexandrino (CIAA) - Rio de Janeiro, RJ, Brazil
}

\begin{abstract}
This paper aims to assess the technical efficiency of Brazilian public container terminals due to the competitiveness required in this sector. An efficiency ranking was established applying the Grey Relational Analysis method to all the Brazilian public containers. After that, the efficiency levels were forecasted for the year 2052, considering the historical data of terminals' activity, the amount of used resources and their nominal capacities. The findings shows that the most efficiency terminals did not reach above $80 \%$ efficiency, even considering that they are the ones that best allocate their assets based on their demand. Furthermore, the improvement of technical efficiency of terminals does not depend only on the spare capacity; it must be a combination of resources, based on the increase in demand.
\end{abstract}

Keywords: port, analysis, ranking, forecast, technical efficiency, container, Brazilian public terminals, Grey Relational Analysis. 
Brazilian Journal of Operations \& Production Management

Volume 13, Número 3, 2016, pp. 386-398

DOI: 10.14488/BJOPM.2016.v13.n3.a15

\section{INTRODUCTION}

Brazilian economy is based on producing and exporting different kinds of goods, such as minerals and agricultural commodities, while manufactured and semi-manufactured products are imported. According to SEP (2012), Brazilian port sector concentrates more than $90 \%$ of the total exportations, every year. In 2010, $96 \%$ of the exportations and $88 \%$ of the importations were held by sea, which represented $83 \%$ of the exported commercial value (US\$ FOB) and $73 \%$ of the imported value (ANTAQ, 2011).

Also, according to ANTAQ (2012a), $11.85 \%$ of the Brazilian goods were moved into the containers in 2010; which were the third biggest in terms of amounts moved, and the first in terms of monetary values, among the total operated cargo (ANTAQ, 2012b). Besides, according to ABRATEC (2012a) the total amount of containers handled, in Brazil, increased from 2.8 million in 2003 to 4.8 million in 2010 (171\%).

Furthermore, Brazil has the largest port in Latin America and 38th in the world, considering the container traffic. Due to the opening of two private terminals in 2013, the capacity of this port has been increased to around 104 movements per hour, above the global average (Santos, 2014).

Worldwide, due to the growth of world trade, new ports have opened increasing competiveness in this market. Then, ports have to invest in new equipment and dredge canals to receive more technically advanced ships to continue competing in this sector (Cullinane, 2006).

Thus, efficiency remains so important for the performance of a given port terminal. However, the efficient of operations depends on the suitable planning of the port's infrastructure, including areas for loading/unloading and container-storage operations, in addition to the necessary equipment, vehicles and workforce, while taking the existing and potential demand into account.

Hence, an adequate planning of the container terminals is required, right from the platforms, straight to the land access points, as means to avoid operational restrictions that could influence the performance indexes and the economic viability levels (Silva, 2010).

ABRATEC (2012a) points out the fact that Brazil counts with 15 container terminals in organized ports, which are stateowned ports, having an important potential for expansion. In 2013, for instance, Brazilian ports moved 338.3 million tons, an increase of $6.8 \%$ compared to the year 2012 (ANTAQ, 2013). Nevertheless, a disorderly and non-planned growth could result in negatives impacts over the operations. So, it is necessary to assess and analyze the present and future efficiency of the Brazilian public terminals.

Taking the increasing demand of containers into account (ILOS, 2012), it is clear that, a study including the current capacities of the terminals, their technical efficiency and future demand projections is necessary.

Considering that world trade has been increasing since 1996 - with exception of 2009 (UNCTAD, 2014), the relevance of this research theme is justified. For this reason, this study can be applied to other ports that have the same characteristics as the state-owned ports in Brazil.

Then, the present work aims to answer the following questions: (1) What are the current structural configurations of the Brazilian container terminals? (2) If compared, which of them are more efficient? (3) What is the future efficiency of the terminals, considering the forecasts of their demand growth?

Based on that, the main goal of this paper is to assess the technical efficiency of the operations in Brazilian public container terminals, considering the current and the projected demand (based on the nominal capacity). Besides, specific objectives include the following: (1) to determine the current potential of containers operation in Brazilian public terminals; (2) to compare the performance levels of the Brazilian public container terminals; (3) to forecast a larger demand for the future in each terminal; and (4) to analyze the current and future levels of efficiency of terminals, regarding demand and capacity.

In this sense, the research aims only to analyze the technical efficiency of terminals, besides the future efficiency levels by using projected levels of demand, through secondary growth data. However, current efficiency is sometimes based on data from 2011, due to the lack of availability of updated information in some cases.

Following this Introduction (Section 1), this paper contains 5 more sections, including: (2) theoretical approach on the efficiency levels in the Brazilian container terminals; (3) methodological procedures; (4) development of efficiency levels assessment of Brazilian container terminals; (5) final considerations and, finally, (6) references.

\section{EFFICIENCY IN THE BRAZILIAN CONTAINER TERMINALS}

According to Antão et al. (2016), ports have become very complex systems due to the variety of cargoes that they may handle, their close location to the local community or the range of interests and responsibilities of the parties involved. Intermodal terminals provide loading, unloading and cargo concentration and dispersion operations with speed and safety, in order to reduce the periods of time for usage of the vehicles and handling equipments, thus reducing the operating costs. Then, a port (or a specific port terminal, e.g. container) can be considered an intermodal terminal (Baldassara et al., 2010; Boschian et al., 2010).

Brazil has 15 public container terminals that are based in 4 regions - South, Southeast, North and Northeast. Their 
characteristics vary according to the type of operations held in each one of them (ABRATEC, 2012b). Table 1 presents their location, the equipment composition, the direct workforce and infrastructure.

Given the fact that each region has a particular behavior, Fleury (2012) proposes to separate the container terminals in clusters or systems, according to geographical traits and market characteristics. Doni (2004) states that the clusters are set out by groups of companies and institutions that happen to interact, producing synergies, which makes it possible for them to respond to continuous growth, beyond a simple group, geographically close and belonging to a specific sector.

In Brazil, there are six clusters for the container terminals of public use, according to their location in similar regions (geographically and in terms of their markets), including (ILOS, 2012): Far South (RS), South (SC e PR), Santos (SP), East (RJ e ES), Northeast (BA, PE e CE) and North (PA). Table 2 shows the operations in container terminals (outputs of the process) between 2006 and 2011 (in TEUs - Twenty Feet Equivalent Units), considering the inputs presented in Table 1.

Table 1. Resources spent in public container terminals in 2011

\begin{tabular}{|c|c|c|c|c|c|c|c|c|c|c|c|c|}
\hline Terminal & Port & 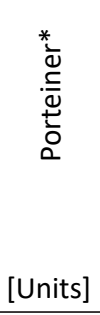 & $\stackrel{\cup}{\text { Y }}$ & 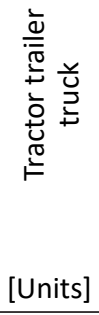 & $\begin{array}{c}\frac{\bar{d}}{\overline{\frac{D}{2}}} \\
\frac{1}{\frac{1}{\delta}} \\
\text { ज } \\
\text { [Units] }\end{array}$ & 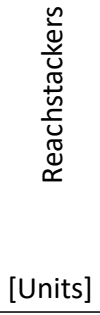 & 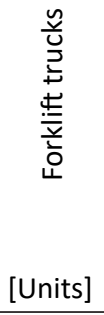 & $\begin{array}{c}\stackrel{\bullet}{\leftarrow} \\
\text { [Units] }\end{array}$ & 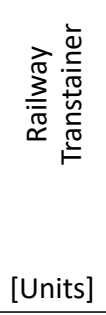 & 产 & 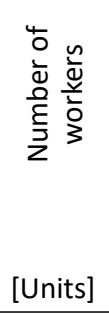 & 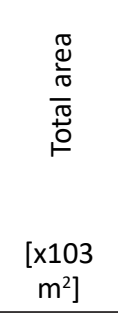 \\
\hline $\begin{array}{l}\text { Tecon } \\
\text { Santos }\end{array}$ & Santos & 14 & 11 & 0 & 0 & 34 & 5 & 22 & 2 & 4 & 2,500 & 596,000 \\
\hline $\begin{array}{l}\text { Libra } \\
\text { Santos }\end{array}$ & Santos & 7 & 0 & 0 & 0 & 0 & 22 & 20 & 0 & 5 & 894 & 380,000 \\
\hline Tecondi & Santos & 3 & 4 & 0 & 0 & 15 & 2 & 6 & 0 & 5 & 862 & 105,380 \\
\hline Rodrimar & Santos & 3 & 3 & 18 & 24 & 25 & 17 & 0 & 0 & 2 & 400 & 70,000 \\
\hline Libra Rio & $\begin{array}{l}\text { Rio de } \\
\text { Janeiro }\end{array}$ & 3 & 1 & 24 & 24 & 13 & 19 & 0 & 0 & 2 & 539 & 140,000 \\
\hline Multirio & $\begin{array}{l}\text { Rio de } \\
\text { Janeiro }\end{array}$ & 2 & 3 & 20 & 20 & 16 & 0 & 0 & 0 & 2 & 561 & 185,000 \\
\hline $\begin{array}{l}\text { Sepetiba } \\
\text { Tecon }\end{array}$ & Itaguaí & 4 & 2 & 17 & 12 & 14 & 27 & 2 & 0 & 2 & 499 & 400,000 \\
\hline $\begin{array}{l}\text { Vila } \\
\text { Velha }\end{array}$ & Vitória & 2 & 2 & 16 & 16 & 6 & 15 & 3 & 1 & 2 & 384 & 108,000 \\
\hline $\begin{array}{l}\text { Tecon Rio } \\
\text { Grande }\end{array}$ & $\begin{array}{l}\text { Rio } \\
\text { Grande }\end{array}$ & 4 & 5 & 32 & 36 & 18 & 29 & 4 & 0 & 2 & 806 & 735,000 \\
\hline TCP & $\begin{array}{l}\text { Paranaguá } \\
\text { and } \\
\text { Antonina }\end{array}$ & 3 & 1 & 16 & 18 & 2 & 8 & 7 & 7 & 2 & 360 & 302,800 \\
\hline Teconvi & Itajaí & 3 & 3 & 0 & 0 & 18 & 0 & 0 & 0 & 4 & 540 & 180,000 \\
\hline TESC & $\begin{array}{l}\text { São } \\
\text { Francisco } \\
\text { do Sul }\end{array}$ & 0 & 4 & 0 & 0 & 10 & 5 & 0 & 0 & 1 & 84 & 30,000 \\
\hline Suape & Suape & 4 & 0 & 0 & 0 & 7 & 15 & 4 & 2 & 3 & 470 & 290,000 \\
\hline $\begin{array}{l}\text { Tecon } \\
\text { Salvador }\end{array}$ & Salvador & 2 & 1 & 20 & 35 & 9 & 20 & 2 & 2 & 2 & 400 & 73,443 \\
\hline Convicon & $\begin{array}{l}\text { Vila do } \\
\text { Conde }\end{array}$ & 0 & 1 & 32 & 32 & 4 & 7 & 0 & 0 & 1 & 140 & 100,000 \\
\hline
\end{tabular}


There is an evident growth in the levels of containers handling, in TEUs, between 2006 and 2011, though during 2009 the crisis coming from the North American Market explains a temporary fall in those levels. In this paper, the handling of containers until 2011 was considered on the basis of available data on the resources linked to this year. The growth of some terminals (Table 2) did not take place uniformly, which could be attributed to the economic perspectives in each Brazilian region.

According to ABRATEC (2012b), the operations with containers in Brazilian public terminals have reported increased growth rates due to rising demands, larger operation efficiencies in the specialized terminals, investments in construction works, procurement of modern equipment and specialized workforce.

As stated by ILOS (2012), the amount of containers handled in Brazilian ports tend to double during the following ten years, reaching grow rates of up to $7,4 \%$ every year, between 2012 and 2021. Nevertheless, this increase will need to come along with a raising capacity, in a way the demand of the period gets to be covered.

According to Hijjar et Alexim (2005), in a context of accelerated growth, to measure the ports' performance, along with their efficiency levels, is an important parameter to contribute to the planning of ports' operations, both at a national and at regional echelons. According to Petrônio et al. (2009), efficiency is the relation between what was obtained from a process (output) and what was used in terms of resources (input) needed to production.

Belloni (2000) states that technical efficiency (or productive efficiency) refers to the ability to prevent wastes, by producing as many results as used resources could make it possible, or by using as few resources as possible for a given production result. According to different studies: Koopmans (1951) apud Färe et al. (1994) and Charnes et al. (1978), the calculation of efficiency measures that relates the results of a process on the basis of the used resources, is represented by Equation 1.

$$
\text { Efficiency }=\frac{\text { outputs }}{\text { inputs }}
$$

Hijjar et Alexim (2005) state that the management of the operations in the container terminals contributes to their efficiency. The search for a better efficiency in the operations of a terminal is essential to reduce the time that the vehicles spend in there, to prevent idle equipment and to avoid the need for workforce beyond pre-determined patterns. Thus, to understand the efficiency concept becomes fundamental, mainly in ports that are considered complex enterprises, with different kinds of inputs and outputs (Wang et al. 2002).

Table 2. Nominal capacity and use of the container terminals of public use in Brazil

\begin{tabular}{|c|c|c|c|c|c|c|c|c|c|c|c|}
\hline \multirow{2}{*}{ Terminal } & \multicolumn{7}{|c|}{ Handled Quantity [in 1,000 TEU'S] } & \multirow{2}{*}{$\begin{array}{c}\text { Nominal } \\
\text { Capacity } \\
\text { [in } 1,000 \\
\text { TEUS] }\end{array}$} & \multirow{2}{*}{ Clusters } & \multirow{2}{*}{$\begin{array}{l}\text { Nominal } \\
\text { Capacity of } \\
\text { the cluster } \\
\text { [in TEUs] }\end{array}$} & \multirow{2}{*}{$\begin{array}{c}\text { Projected } \\
\text { Growth } \\
\text { Rate [\% } \\
\text { year] }\end{array}$} \\
\hline & 2006 & 2007 & 2008 & 2009 & 2010 & 2011 & $\begin{array}{c}\text { Variation } \\
\text { [\%] }\end{array}$ & & & & \\
\hline Tecon Santos & 1,117 & 1,235 & 1,164 & 981 & 1,274 & 1,408 & $26 \%$ & 2,000 & Santos & \multirow{4}{*}{4,430} & \multirow{4}{*}{5.3} \\
\hline Libra Santos & 689 & 806 & 899 & 729 & 902 & 895 & $30 \%$ & 1,500 & Santos & & \\
\hline Tecondi & 258 & 285 & 322 & 278 & 372 & 497 & $93 \%$ & 700 & Santos & & \\
\hline Rodrimar & 234 & 201 & 193 & 197 & 181 & 197 & $-16 \%$ & 230 & Santos & & \\
\hline Libra Rio & 179 & 202 & 216 & 181 & 222 & 207 & $16 \%$ & $600 *$ & East & \multirow{4}{*}{2,320} & \multirow{4}{*}{7.2} \\
\hline Multirio & 175 & 186 & 212 & 180 & 220 & 257 & $47 \%$ & 670 & East & & \\
\hline Sepetiba Tecon & 259 & 229 & 315 & 225 & 295 & 320 & $24 \%$ & 500 & East & & \\
\hline Vila Velha & 238 & 260 & 271 & 202 & 241 & 260 & $9 \%$ & 550 & East & & \\
\hline $\begin{array}{l}\text { Tecon Rio } \\
\text { Grande }\end{array}$ & 575 & 587 & 626 & 656 & 666 & 639 & $11 \%$ & 1,350 & Far South & 1,350 & 6.6 \\
\hline TCP & 494 & 595 & 614 & 634 & 680 & 710 & $44 \%$ & 1,200 & South & \multirow{3}{*}{2,440} & \multirow{3}{*}{7.0} \\
\hline Teconvi & 549 & 496 & 359 & 197 & 384 & 385 & $-30 \%$ & 740 & South & & \\
\hline TESC & 219 & 226 & 237 & 190 & 160 & 186 & $-15 \%$ & $500 *$ & South & & \\
\hline Suape & 196 & 241 & 294 & 251 & 340 & 435 & $122 \%$ & $700 *$ & Northeast & \multirow{2}{*}{1,300} & \multirow{2}{*}{8.9} \\
\hline Tecon Salvador & 250 & 246 & 236 & 234 & 262 & 262 & $5 \%$ & 600 & Northeast & & \\
\hline Convicon & 31 & 29 & 24 & 28 & 35 & 33 & $6 \%$ & 500 & North & 500 & 6.7 \\
\hline
\end{tabular}


For a better understanding of the matter, studies on port terminals (maritime and inland) were reviewed. Cullinane et al. (2006), Almawshekia et Shahb (2015), Lu, Park et Huo (2015) assess the technical efficiency of container terminals by using the Data Envelopment Analysis (DEA) while González et Trujillo (2008) et Serebrisky et al. (2016) by applying the Stochastic Frontier Analysis (SFA). When studying the impact of the privatization of the port sector, Tongzon et Hen (2005) analyze critical factors for competitiveness and efficiency in container terminals by using SFA. Clark et al. (2004) assess the port efficiency from a financial perspective, taking the maritime shipping costs into account.

About the research on Brazilian terminals, Bertoloto et Soares de Mello (2011) do not only refer to container terminals. Their perspective also considers general cargo, as well as solid, liquid and mixed cargoes. It even refers to terminals for private use, using the DEA to calculate the efficiency. In another research, Wanke et Barros (2015) assess the impacts of public-private partnerships on major Brazilian public ports. The authors also use DEA in their methodology to propose that these kinds of arrangements with private terminal operators could help achieving higher levels of scale efficiency.

Rios (2005) refers to relative efficiency in container terminals belonging to MERCOSUL, focusing on Brazil, Argentina and Uruguay. Tovar et Ferreira (2006) address the growth of the efficiency in Brazilian ports after the port modernization law in 1993 and the need to promote the sector.

Cortez et al. (2013) address the study of efficiency as a basis for future decisions taken by port authorities. Previous to that, Macedo et Manhães (2010) et Fontes (2006) showed their perspective on efficiency without considering the decision making approach to improve performance.

Barros et al. (2011) assess the efficiency by focusing on berth allocation from ports of solid cargo, specifically from mining, taking into account the stocked amounts in order to do the scheduling of ships.

Guimarães et al. (2014) and Morini et al. (2014) study Brazilian public containers terminals applying DEA, but the former focused in eco-efficiency and the latter in efficiency. Serebrisky et al. (2016) assess the technical efficiency of container ports in Latin America and the Caribbean (including Brazil) using an input-oriented stochastic frontier model. Pérez, Trujillo et González (2016) analyze the evolution of efficiency of container terminals from 2000 to 2010 in Latin American and Caribbean (including nine Brazilian terminals), by applying the stochastic production frontier. Wilmsmeier, Tovar et Sanchez (2013) also evaluates this region (including Rio de Janeiro and Santos ports and four Spanish ports), applying DEA to the data gathered from 2005 to 2011. In a slight different focus, Siqueira et al. (2016) show the results of performance assessments of fifteen container terminals in Brazil, using eco-efficiency and technical efficiency measures.

In this sense, none of the papers addressed the current efficiency and its projection on the basis of increase of demand, as means to explain the differences in performance in different moments, which actually represents the gap being filled in the research presented in this paper. Besides, Almawshekia et Shahb (2015) state that there are still limited studies on container terminals in developing countries which reinforces the relevance of this paper.

\section{METHODOLOGICAL PROCEDURES}

Bibliographic and document research allowed to access relevant data sources on the topic, besides promoting the choice of a method to be used in the assessment of the efficiency of the Brazilian container terminals.

In sequence, documents and reports about the addressed regulatory authorities and terminals were searched; nonstructured interviews were held with specialists; and technical visits were performed in some terminals.

In order to calculate the efficiency, Equation 1 was applied, considering container operations as outputs and the used resources in terminals as inputs. Thus, for each terminal, different measures were taken, before being consolidated in a single efficiency result. Because the measures included different units and scales, it was necessary to use an aggregation technique to subsequently rank diverse efficiency results.

The technique has been chosen based on the problem's characteristics and the most suitable context and structure (Almeida et Costa, 2003).

So, a multi-criteria technique called Grey Relational Analysis (GRA) was applied, since besides it responded to the characteristics of the decision-making problem, it presented the possibility of working with limited data quality to assess the behavior of an uncertain system (Deng, 1989; Liu et Lin, 2006; Wen, 2004).

According to Deng (1989), the GRA mathematic model is based on a group of observations $\left\{x_{0}^{(0)}, x_{1}^{(0)}, \ldots, x_{m}^{(0)}\right\}$, where $x_{0}^{(0)}$ is a reference observation, and $x_{1}^{(0)}, x_{2}^{(0)}, \ldots, x_{m}^{(0)}$ are original observations to be compared. Each $x_{i}$ observation includes $n$ measures that are described in terms of sequence $x_{i}^{(0)}=\left\{x_{i}^{(0)}(k), \ldots, x_{m}^{(0)}(n)\right\}$, where each component of such sequence is normalized, before any operation, like this:

If the bigger the better, then Equation 2 is used:

$$
\mathrm{Xi}^{\prime}(\mathrm{k})=\frac{x_{i}^{(0)}(k)-\min \left(x_{i}^{(0)}(k)\right)}{\max \left(x_{i}^{(0)}(k)\right)-\min \left(x_{i}^{(0)}(k)\right)} \quad \text { for i: } 0 \ldots \mathrm{m}, \quad \mathrm{k}: 1 \ldots \mathrm{n}
$$


Brazilian Journal of Operations \& Production Management Volume 13, Número 3, 2016, pp. 386-398 DOI: 10.14488/BJOPM.2016.v13.n3.a15

If the smaller the better, then Equation 3 is used:

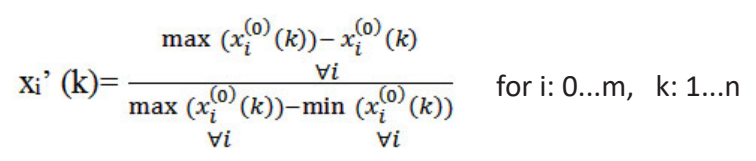

Where: $x_{i}^{\prime}(k)$ is the normalized value of measure $k$ for an original observation $x_{i}^{(0)}$. The sequence which normalized attributes are the best possible, representing the desired state for any sequence, is represented by $x_{0}$, being the values of the sequence equal to 1 . That approach offers an outline for all the cases in which a reference measure is not easily found or calculated.

After normalization data in each sequence, grey relational coefficients $\gamma$ are calculated, according to Equation 4:

$$
\gamma\left(x_{0}^{\prime}(k), x_{i}^{\prime}(k)\right)=\frac{\underset{\min \min \left|\mathrm{x}_{0}(\mathrm{k})-\mathrm{x}_{\mathrm{i}}(\mathrm{k})\right|+\zeta \operatorname{maxmax} \mid \mathrm{x}_{0}(\mathrm{k})-\mathrm{x}_{\mathrm{i}}(\mathrm{k})}{\forall \mathrm{i} \quad \forall \mathrm{k}}}{\forall \mathrm{k}}
$$

Where $\zeta \in[0,1]$ assumes, in general terms, a value of 0.5 , helping only to differentiate the elements of the sequence, and not having any influence in the final order of the sequences (Deng, 1989). After establishing grey relational coefficients, grey relational degrees must be established $\left(\Gamma_{i}\right)$ for each sequence of data (Deng, 1989), according to Equation (5).

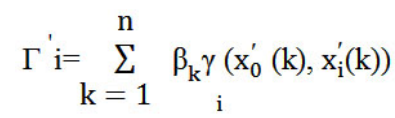

Where is the weight for each measure, and $\sum_{j=1}^{n} \beta_{\mathrm{k}}=1$.

After using GRA, it was possible to calculate the current efficiencies in each terminal, to compare them and forecast the efficiencies according to the growth of the handlings or operations of containers (outputs).

\section{FINDINGS}

Based on Table 1, technical efficiency measures were calculated for the terminals (using Equation 1), considering outputs (handlings-operations) and inputs (equipment, vehicles, infrastructure and workforce with contract of employment).

After calculating the efficiency measures, Grey Relational Analysis method was used, along with Equation 2 (the more efficiency, the better performance of the terminal), 4 and 5 (considering the same importance for all measures). This procedure ended up in Grey Relational Ranking, using the grey relational degree as the efficiency of the terminals, according to Figure 1.

Analyzing Figure 1, it is possible to verify that the three more efficient terminals are respectively: Libra Santos and Tecon Santos, both located in Santos, and TESC located in Santa Catarina.

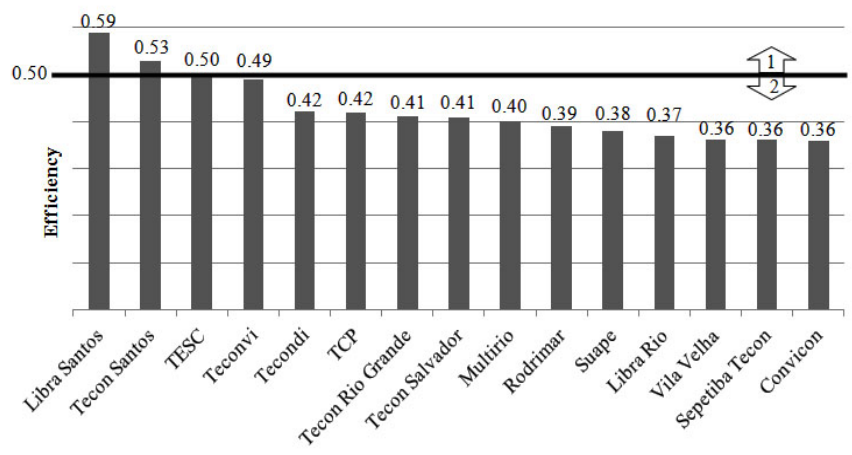

Figure 1. Ranking of terminals according to their technical efficiency Note: ${ }^{1}$ moderate efficiency; ${ }^{2}$ lower efficiency

It becomes possible to check that the efficiency levels of a terminal do not only depend on its operational demands, even though this influences the result. Nevertheless, the three terminals with higher levels of handling-operations with containers in 2011 (Libra Santos et Tecon) are also between the leaders in efficiency.

For further analyses, three groups were set, where the terminals were classified according to its levels of efficiency (Pareto), like this: A: Superior Efficiency (Above $80 \%$ on the Grey relational degree scale) - No terminal was classified in that group. B: Moderate Efficiency (Between 50\% and $79 \%$ on the Grey relational degree scale) - including Libra Santos, Tecon Santos and TESC. C: Inferior Efficiency (Under 49\% on the Grey relational degree scale) - The rest of the terminals that were not included in $A$ or $B$, belong to this group.

Libra Santos and Tecon Santos terminals, with a moderate level of efficiency, have a longer period of functioning, ever since 1995. The two firsts are located in Santos Port, currently having higher demand and a privileged geographical localization.

TESC terminal, founded in 2001, showed a demand below half of its maximum capacity in 2011. However, this terminal has a reduced number of equipment for its operations, being the possible cause for its good performance.

The terminals in the group C (lower efficiency), are those that started their operations after the formers, showing lower demand. These tend to have a superior idle capacity (Table 2) and a greater area destined for future expansions, if necessary.

Considering that many terminals with low performance levels also have levels of idle capacity and perspectives of a higher level of activity in the future, a projection of their technical efficiency was made, considering an increasing demand. Such projection comes from the principle that states that if the inputs keep the same along with a growing demand, the efficiency level in each case will be changed.

For the projection of the technical efficiencies, a linear growth rate was used (ILOS 2012) for each the terminals, until these achieved, year by year, their maximum operational 
capacities. Since projections are always comparative, when a terminal achieves its maximum capacity, it continues being compared to others, however, with stable operations and on the limits of its capacity. Resources used kept the same, once they represent the current and maximum capacity of the terminals.

Figure 2 presents the evolution of the efficiency levels of the terminals until 2052, when the last terminal achieves its maximum capacity. Levels of efficiency for the years when one (or more) terminals achieve their maximum capacities are presented. Anyway, efficiency assessment here is comparative. Therefore, with the enhancement of a terminal's performance, another terminal may get worse, even if it maintains or increases its operations.

It turns out that, even with a higher number of containers handled, ten out of fifteen terminals obtained a projected level of efficiency practically equal to their current levels, with variations of up to approximately $5 \%$, including: Libra Santos, Tecondi, Rodrimar, Libra Rio, Multirio, Sepetiba Tecon, Vila Velha, TESC, Suape and Tecon Salvador. Nevertheless, some terminals presented relevant differences between the analyzed efficiencies in the two moments. Tecon Rio Grande, Teconvi and Convicon stand out, for having climbed 1, 2 and
11 positions in the ranking, respectively; besides, Tecon Santos stands out for having dropped 2 positions, while TCP dropped in 6 . These terminals showed variations of their efficiencies of $8 \%, 11 \%, 28 \%,-6 \%$ and $-11 \%$, respectively, between 2011 and 2052 .

In order to explain the efficiency variations, we supposed that a terminal with greater current idle capacity would have more possibilities to enhance their efficiency levels. Although, this assumption was refuted by analyzing Figure 3 that shows current efficiencies (2011), on the axis of the abscissa, and projected (2052) on the axis of the ordinate. The size of the circles represents the current idle capacity.

In order to group the terminals, Quadrants were established based on current and projected efficiency measures. Quadrant II is the desired one, where both, current and projected efficiencies, would be the greatest, comparatively.

Quadrant IV represents the undesired position for a terminal, because, comparatively, it groups those with both low current and projected performances. Quadrant I groups the terminals with a low current performance and a high projected one, while Quadrant III groups those with a high current performance and a low projected one.

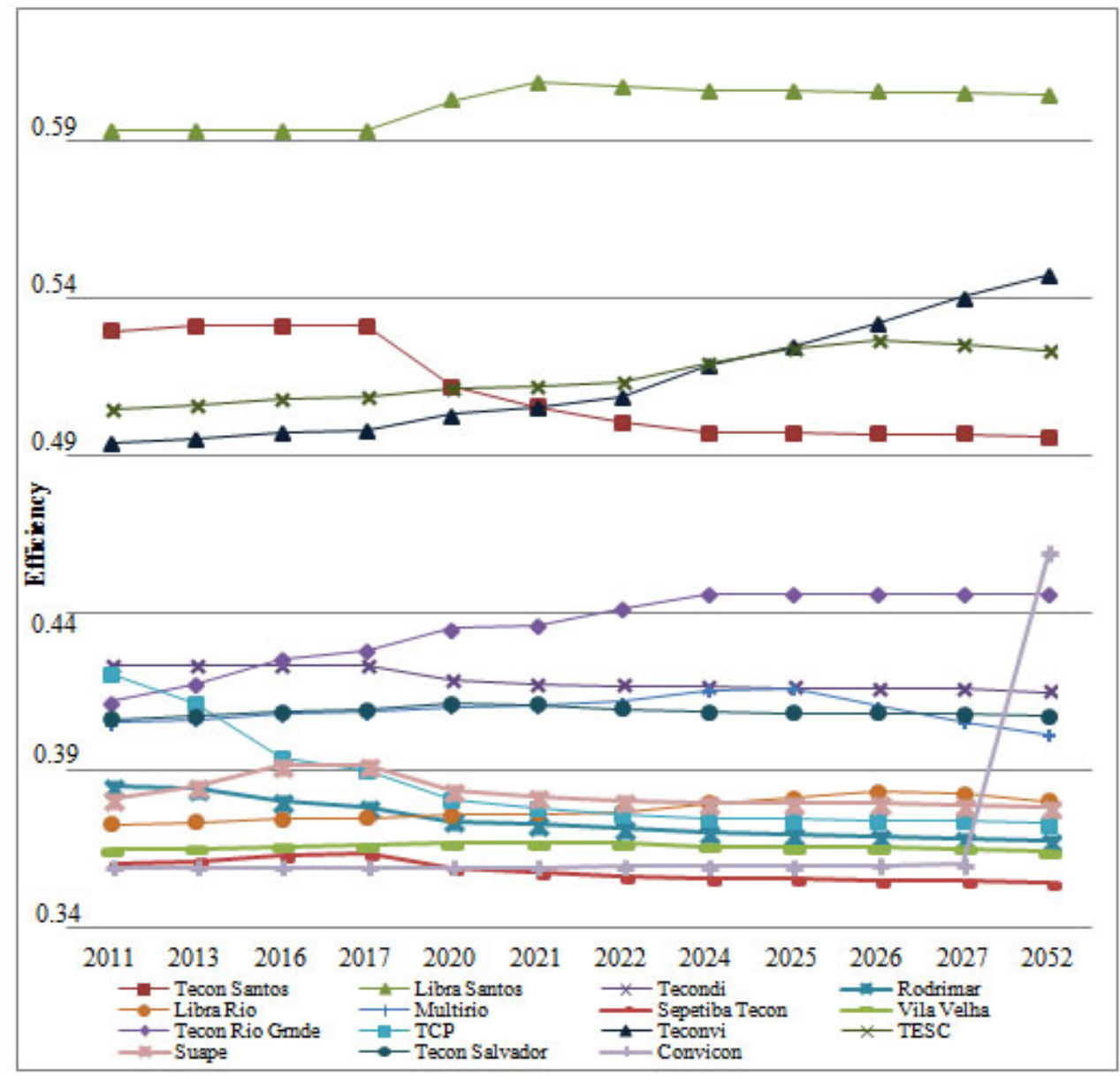

Figure 2. The evolution of the efficiency levels of the terminals until 2052 
Brazilian Journal of Operations \& Production Management

Volume 13, Número 3, 2016, pp. 386-398 DOI: 10.14488/BJOPM.2016.v13.n3.a15

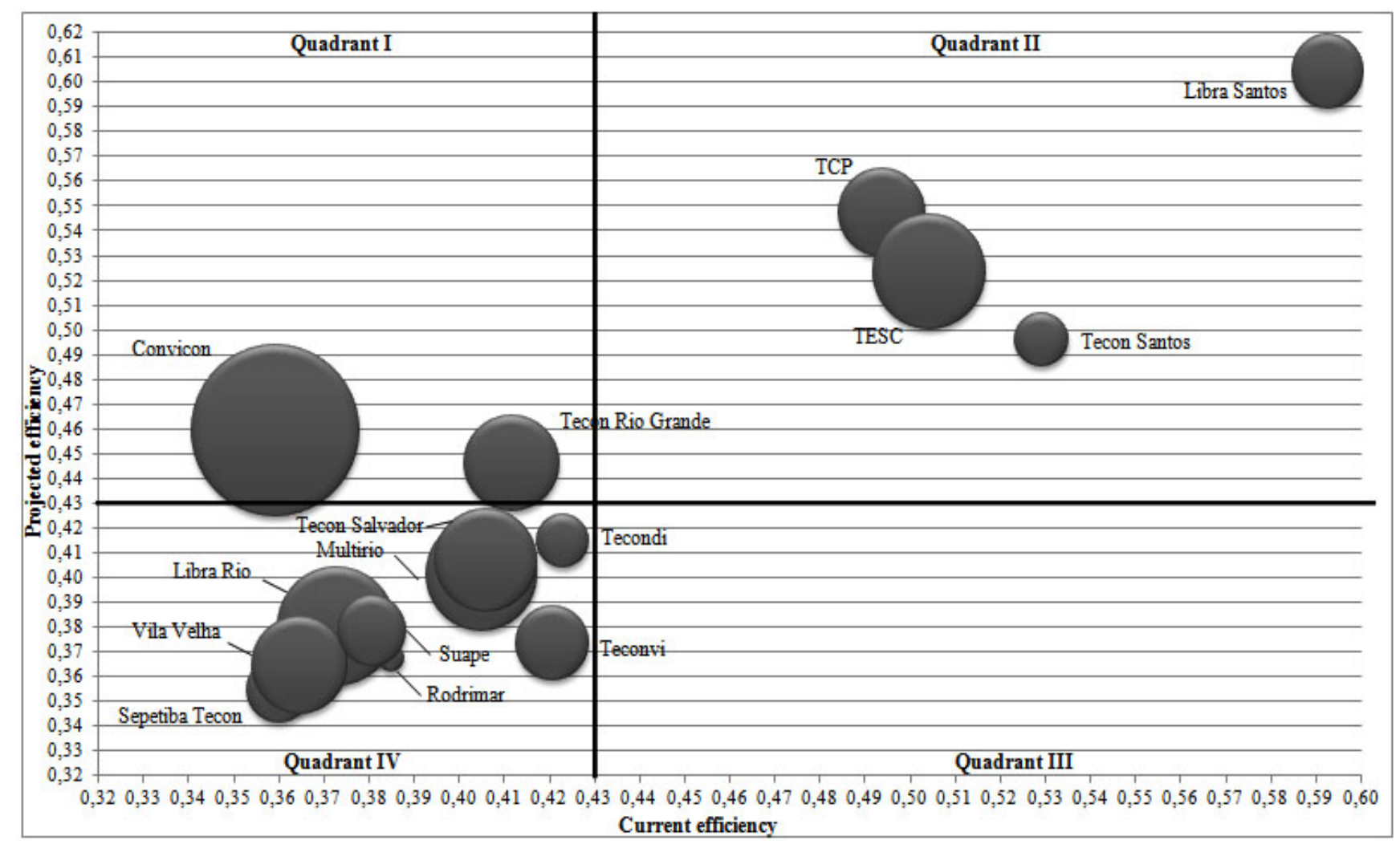

Figure 3. Current efficiencies (2011) and projected efficiencies (2052) of the terminals

On Quadrant I, it appears that Convicon, which enhanced its projected efficiency levels, has the greater idle capacity among all the terminals. However, the idle capacity is not the only factor that influence the enhancement in efficiency since Tecon Rio Grande has a low current idle capacity and showed improvements compared to, for example, Libra Rio and Multirio, according to Table 2.

On Quadrant II, Libra Santos stands out for maintaining its ranking leadership until 2052. TESC and TCP enhanced their efficiency levels, while Tecon Santos reduced it in terms of its projection to the future. Despite the performance differences during the two moments analyzed, such terminals appear on the same Quadrant, both in 2011 and 2052.

No terminal has appeared on Quadrant III, meaning that none of them having a greater current performance, showed any enhancement that would relocate them on Quadrant II, (which would have been a desired situation).

On Quadrant IV are placed the terminals which efficiency levels did not practically change, regardless of their idle capacity. This analysis leads to another research: Is the enhancement of the efficiency associated with to the composition of the used resources?

In this case, two pairs of terminals were compared: (1) Libra Santos (the first on the ranking) and Tecon Rio Grande with capacity levels between 1,500,000 and 1,350,000 TEUs per year, respectively; and, (2) Sepetiba Tecon (the last on the ranking) and TESC, with capacity levels of 500,000 TEUS per year.

Among these two pairs, it is noted that Libra Santos and TESC are on Quadrant II, and that Tecon Rio Grande and Sepetiba Tecon are on Quadrants I and IV, respectively. In order to do the analysis, current and projected efficiency levels of Tecon Rio Grande and Sepetiba were calculated, as though as they had the same operational characteristics and the same resources as their peers. The results are found on Figures 4 and 5.

When analyzing Figures 4 and 5, a performance enhancement is evident in the case of Sepetiba Tecon, beyond that of Tecon Rio Grande. Sepetiba Tecon came from the second to last (in 2011) and the last (in 2052) to the second and fourth positions, respectively. Tecon Rio Grande enhanced its performance, by leaving the seventh (in 2011) and sixth positions (in 2052) to occupy the sixth and fifth positions, respectively.

In order to understand the reasons for a better performance on the ranking of Sepetiba Tecon compared to that of Tecon Rio Grande, a comparison of their used resources (Table 1 ) and those of their peers was made. Figures 6 and 7 show the results of Table 1 in the case of the analyzed terminals, considering the standardized values in a way it was possible to place all the resources on a scale from zero to one. 


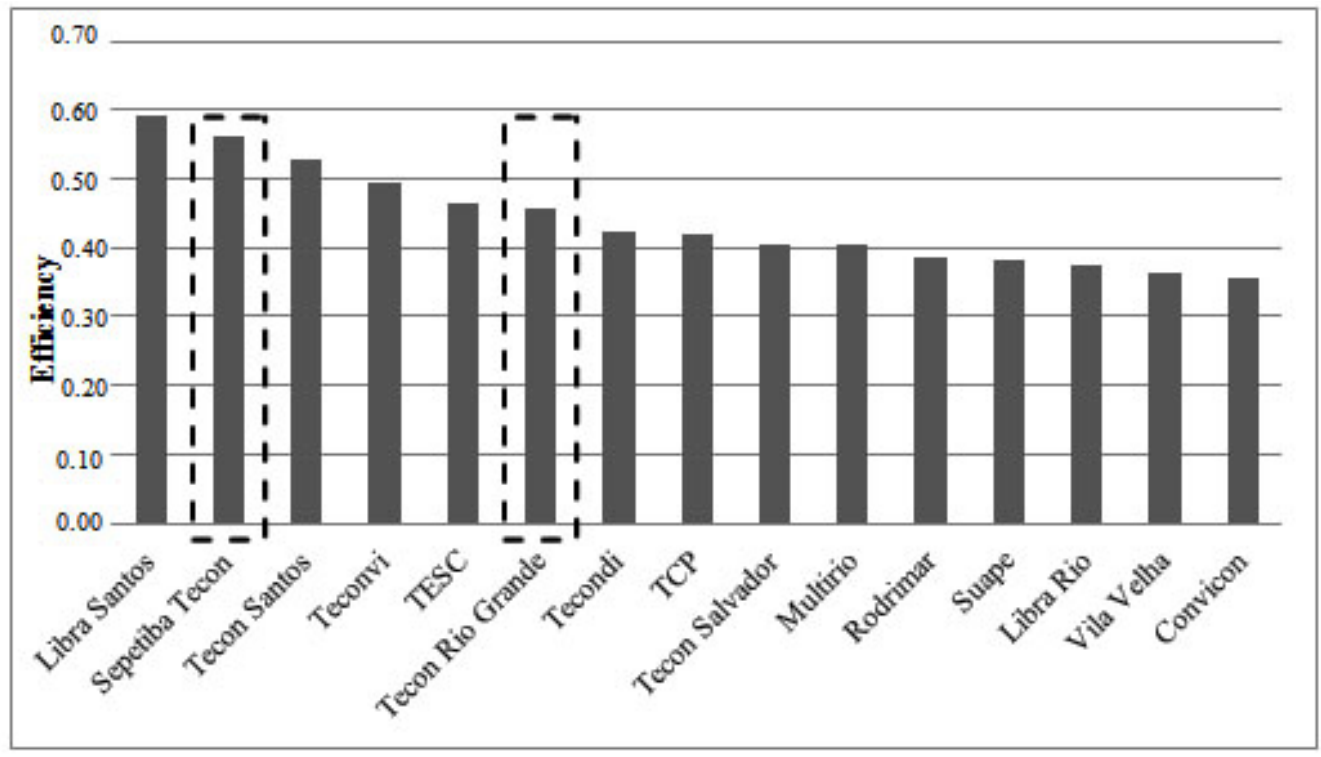

Figure 4. Current efficiency levels of Tecon Rio Grande and Sepetiba

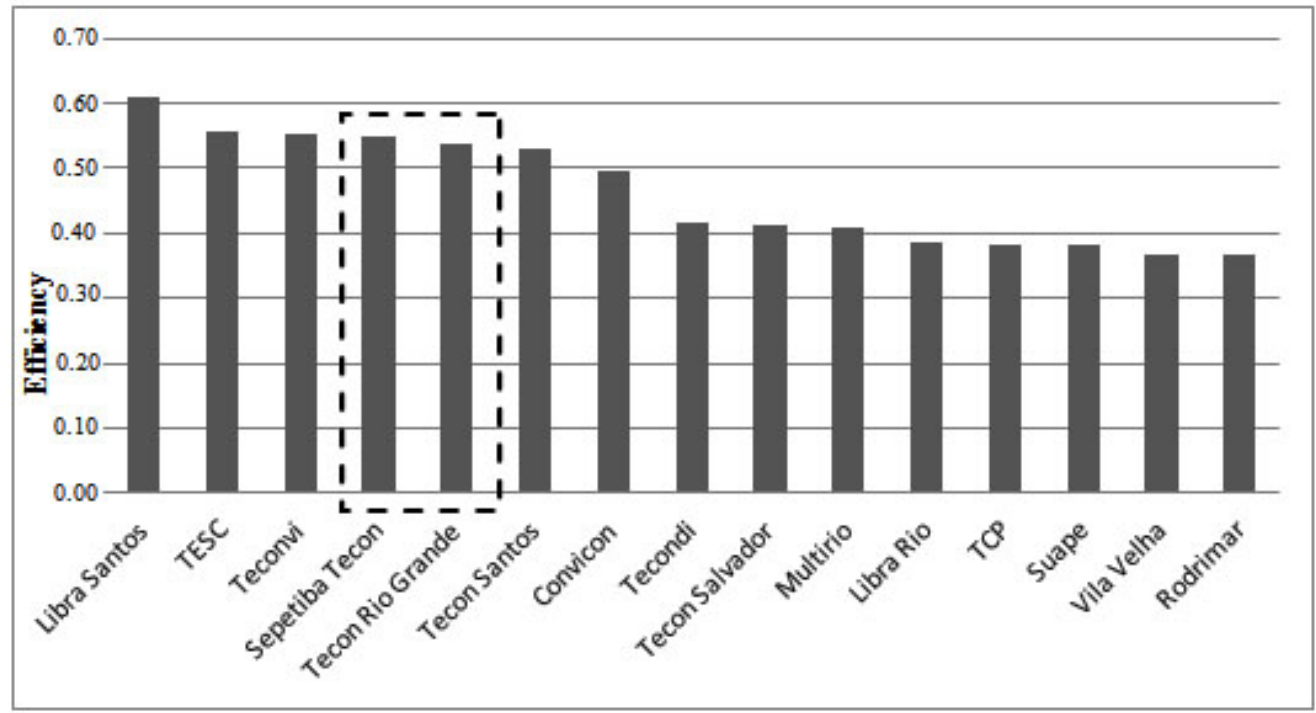

Figure 5. Projected efficiency levels of Tecon Rio Grande and Sepetiba

It turns out that the intersection areas between Libra Santos and Tecon Rio Grande are greater than those of TESC and Sepetiba Tecon, which demonstrated that the difference between the resources used by the first analyzed pair is lower than that of the second.

Thus, for Sepetiba Tecon it would be harder to enhance its performance, compared to TESC, because it has a greater quantity of resources of different kinds devoted to the same operations.

Beyond that, the composition of the equipment may influence the performance of its operations. TESC, for example, has greater amounts of $\mathrm{MHC}$ ground cranes (Mobile Harbor Crane). This equipment may operate up to 30 containers per hour and respond to the ships' needs without any on-board equipment, which may bring more flexibility and efficiency into the operations.

In this way, it would be important that during the planning and management of the processes in the terminals, the composition of the resources took into account the technical specifications for the equipment and its operational potential in the long term, given the growing demand. Generally, the composition of the resources is mainly based on financial feasibility, while this analysis should be combined with future operational needs.

In contrast, investing for future capacity for responding to demand may affect the performance of a given terminal, in terms of its technical efficiency levels. For this reason, the need to adequate the demand planning process to the 


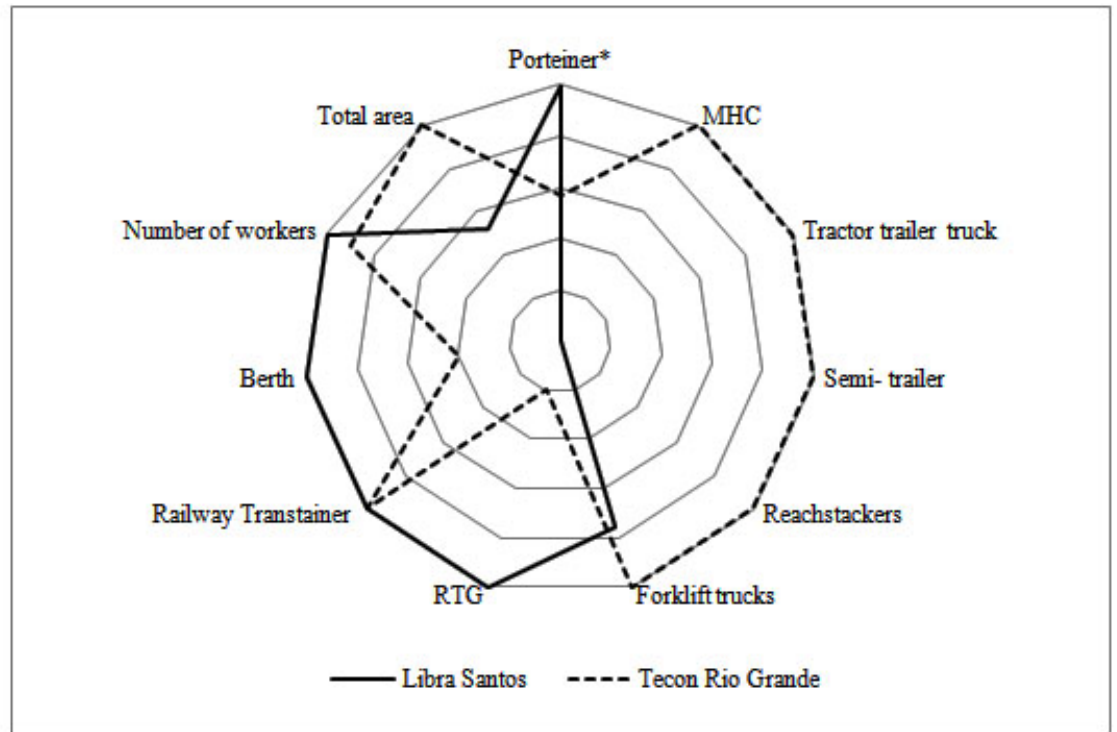

Figure 6. Comparison between resources of the terminals Libra Santos and Tecon Rio Grande (standardized values)

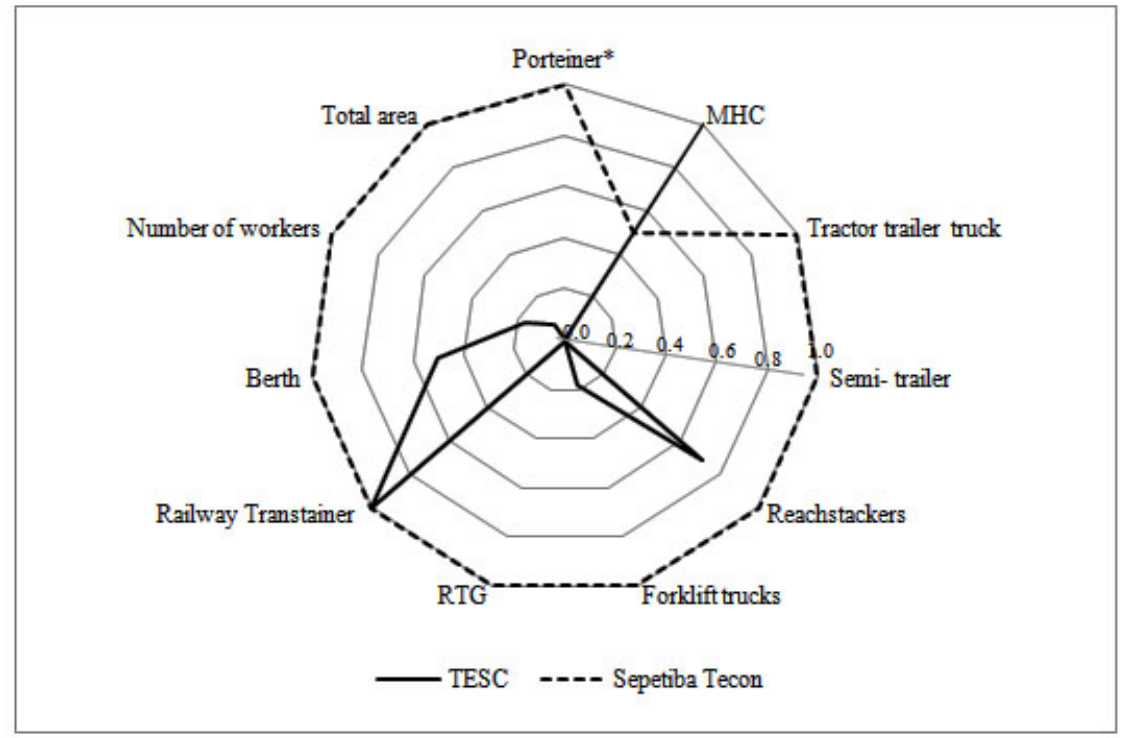

Figure 7. Comparison between resources of the terminals TESC and Sepetiba Tecon (standardized values)

composition of the operational resources is highlighted, considering that the productive resources' idleness also undermines the financial results of the enterprise.

\section{CONCLUDING REMARKS}

In this paper, it was possible to assess and analyze the performance of the Brazilian container terminals, as means to establish a ranking in order to compare their respective efficiencies. With the assessment of the 15 Brazilian terminals of public use, it was possible to verify peculiarities in their operations, both on their inputs and outputs. To establish an efficiency ranking, the Grey Relational Analysis was used, which allowed to certify that the terminals have different results on efficiencies.
Thus, it was possible to answer to the research problem, by settling the current structural configuration of the Brazilian terminal containers and their current efficiency levels, considering their handling-operational growth.

It is possible to highlight that the terminals having a greater efficiency, currently do not necessarily have a greater demand and/or a lower number of resources, but they do have a better combination of those. Therefore, the most efficient are those who allocate their active resources the best, considering their current demand. However, in the future, such configuration may be changed on the basis of the demands and the bottleneck in the operations.

It is important to note that terminals with better efficiency levels in this analysis do not show levels over $80 \%$, 
which would be a greater efficiency, according to the Pareto classification. It can be related to the amount of efficiency measures used, making that no terminals stand out in the most of them.

This research is relevant, once it serves as a basis to elaborate new works focused on the efficiency of the Brazilian container terminals. It was found that, in a comparative analysis, idle capacity does no determine the enhancement of the technical efficiency of the terminals, and that such enhancement, on the basis of a growing demand, must be related to a more adequate composition of resources.

Furthermore, this study could help in the proposal of public policy in the development and competitiveness of ports. The lack of updated data reinforces the need of studies focusing in this sector in Brazil. There is not available information about the terminals' assets after 2011, which did not allow us to compare the results predicted to the real efficiency levels in the recent years.

This study includes limitations that ought to be considered in order to improve the research: as chosen a linear demand growth implies in a high margin of error to be considered until 2052, compared to what will be accomplished. Another limitation is related to the fact of considering the container terminals being isolated from others on the same port. It might be necessary to analyze whether the equipment is used by several terminals. The traits of such equipment ought to be considered, since it may be used for different purposes and their operational and maintenance costs may end up being different.

In this way, new researches may be necessary in order to consider the financial-economic efficiency compared to the technical efficiency, once a terminal can have a lower amount of inputs with higher costs.

It is important to verify the existence of possible input sharing among container terminals on the same port, which could eventually lead to the need of considering their rating, or even, expanding the analysis of the efficiency levels to the port as a whole. Besides, simulation models could be incorporated into the assessment of the efficiency of these terminals.

Another important suggestion would be to raise real data, in the future, to compare real efficiency with the one being projected for a given year. Such analysis could even comprise the comparison of the technical efficiency levels of the Brazilian terminals with that of foreign terminals.

Besides, it is could include the assessment of the execution of certain actions to improve the efficiency levels in a given terminal, as well as its costs, with regard to the revenues obtained through a growing demand. As last suggestion, a performance evaluation aiming to reduce environmental and social impacts could be done.

\section{REFERENCES}

[ABRATEC] Brazilian Association of Public-Use Container Terminals. (2012a). http://www. abratec-terminais.org.br/ desempenho. Access: 8th July, 2015.

[ABRATEC] Brazilian Association of Public-Use Container Terminals. (2012b). http://www. abratec-terminais.org.br/ indices. Access: 8th July, 2015.

[ABRATEC] Brazilian Association of Public-Use Container Terminals. (2012c). http://www. abratec-terminais.org.br/ terminais. Access: 8th July, 2015.

Almawshekia, E. S.; Shahb, M. Z. (2015). Technical Efficiency Analysis of Container Terminals in the Middle Eastern Region. The Asian Journal of Shipping and Logistics. Vol. 31, No. 4, pp. 477-486.

Almeida, A. T.; Costa, A. P. C. S. (2003). Applications with multi-criteria decision support methods. Editora Universitária: Recife, Brazil.

Antão, P.; Calderón, M.; Puig M.; Michail, A.; Wooldridge, C.; Darbra, R. M. (2016). Identification of occupational health, safety, security (OHSS) and environmental performance indicators in port areas. Safety Science. Vol. 85, pp. 266-275.

[ANTAQ] National Agency of Waterway Transportation. (2011). http://www.antaq.gov.br/ portal/pdf/ PanoramaAquaviario6.pdf. Access: 10th July, 2015.

[ANTAQ] National Agency of Waterway Transportation. (2012a). http://www.antaq.gov.br/ Portal/Frota/ ConsultarTotalGeralCarga.aspx. Access: 10th July, 2015.

[ANTAQ] National Agency of Waterway Transportation. (2012b). http://www.antaq.gov.br/ Portal/ DesempenhoPortuario/Index.asp. Access: 10th July, 2015.

[ANTAQ] National Agency of Waterway Transportation. (2012c). www.antaq.gov.br/portal/ pdf/Portos/Itaguai.pdf. Access: 10th July, 2015.

Baldassarra, A.; Impastato, S.; Ricci, S. (2010). Intermodal terminals simulation for operation management. European Transport \Transporti Europei. Vol. 46, pp. 86-99.

Barros, V. H.; Costa, T. S.; Oliveira, A. C. M.; Lorena, L. A. N. (2011). Model and heuristic for berth allocation in tidal bulk ports with stock level constraints. Computers \& Industrial Engineering. Vol. 60, pp. 606-613.

Belloni, J. A. (2000). Productive Efficiency Assessment Methodology in Federal Brazilian Universities. Dissertation, Santa Catarina Federal University, Florianópolis.

Bertoloto, R. F.; Soares de Mello, J. C. C. B. S. (2011). Efficiency Brazilian ports and private terminals with different characteristics. Journal of Transport Literature. Vol. 5, pp. 4-21. 
Brazilian Journal of Operations \& Production Management

Volume 13, Número 3, 2016, pp. 386-398

DOI: 10.14488/BJOPM.2016.v13.n3.a15

Boschian, V.; Dotoli, M.; Fanti, M. P.; lacobellis, G.; Ukovich, W. (2010) A metamodelling approach for performance evaluation of intermodal transportation networks. European Transport\Transporti Europei. Vol. 46, pp. 100-113.

Chang, V.; Tovar, B. (2014a). Efficiency and productivity changes for Peruvian and Chilean ports terminals: a parametric distance functions approach. Transport Policy. Vol. 31, pp. 83-94.

Chang, V.; Tovar, B. (2014b). Drivers explaining the inefficiency of Peruvian and Chilean ports terminals. Transportation Research Part E: Logistics and Transportation Review. Vol. 67, pp. 190-203.

Charnes, A.; Cooper, W. W.; Rhodes, E. (1978). Measuring the efficiency of decision making units. European Journal of Operational Research. Vol. 2, pp. 429-444.

Clark, X.; Dollar, D.; Micco, A. (2004). Port efficiency, maritime transport costs and bilateral trade. Journal of Development Economics. Vol. 75, pp. 417-450.

Cortez, L. C. S.; Oliveira, L. R.; Martins, E. F.; Jesus, I. R. D.; Mello, J. C. C. B. S. (2013). Efficiency analysis in management of Brazilian public ports on the role of port authorities. Journal of Transport Literature. Vol. 7, No. 2, pp. 78-96.

Cullinane, K.; Wang, T. F.; Song, D. W.; Ping, J. (2006). The technical efficiency of container ports: comparing data envelopment analysis and stochastic frontier analysis. Transportation Research Part A. Vol. 40, pp. 354-374.

Deng, J. (1989). Introduction to Grey system theory. Journal of Grey Systems. Vol. 1, No. 1, pp. 1-24.

Doni (2004). Cluster Analysis: methods and hierarchical partitioning. Dissertation, Presbiteriana Mackenzie University, São Paulo.

Färe R.; Grosskopf S.; Lovell K. (1994). Production Frontiers. Cambridge University Press: New York.

Fleury, P. F. (2012). Cargo Transport Panorama in Brazil. Logistics and Supply Chain Management - Planning Flow Products and Resources. Publishing house Atlas: São Paulo.

Fontes, O. H. P. M. (2006). Evaluation of port efficiency through a DEA model. Niterói, Rio de Janeiro.

González, M.; Trujillo, L. (2008). Reforms and infrastructure efficiency in Spain's container ports. Transportation Research Part A. Vol. 42, pp. 243-257.

Guimarães, V. A.; Leal Jr., I. C.; Garcia, P. A. A. (2014). Environmental performance of Brazilian container terminals: a data envelopment analysis approach. Procedia Social and Behavioral Science. Vol. 160, pp. 178-187.

Hijjar, M. F.; Alexim, F. M. B. (2005). Evaluation of access to port and rail containers terminals in Brazil. www. centrodelogistica.com.br/new/fs-panorama_logistico3.htm. Access: 20th July, 2015.

[ILOS] Instituto de Logística e Supply Chain. (2012). http:// portalnaval.com.br/noticia/349 59/carga-em-conteiner-vaidobrar-ate-2021. Access: 17th July, 2015.

[Libra] Libra Terminal Rio (2012). http://www. terminal1rio.com.br/infraestrutura.aspx. Access: 8th July, 2015.

Liu, S.; Lin, Y. (2006). Grey information: theory and practical applications. Springer: London.

Lu, B.; Park, N. K.; Huo, Y. (2015). The Evaluation of Operational Efficiency of the World's Leading Container Seaports. Journal of Coastal Research: Special Issue Recent Developments of Port and Ocean Engineering. Vol. 73, pp. 248-254.

Macedo, M. A. S.; Manhães, J. V. P. (2010). Evaluation of container terminal efficiency in Brazil through Data Envelopment Analysis (DEA). Journal of Business. Vol. 14, pp. 35-53.

Morini, C.; Maurício, M. P. G.; Oliveira, R. C.; Moretti, A. C.; Azevedo, A. T.; Inácio Júnior, E. (2014). Efficiency analysis of Brazilian public container terminals. Business and Management Review. Vol. 4, No. 1, pp. 127-138.

[Multirio] Terminal Multirio (2012). http://www. multiterminais.com.br/e_multirio.html. Access: 8th July, 2015.

Pérez, I.; Trujillo, L.; González, M. M. (2016). Efficiency determinants of container terminals in Latin American and the Caribbean. Utilities Policy. pp. 1-14 (in press).

Petrônio et al. (2009). Production management. 2nd Edition, Publishing house Saraiva: São Paulo.

Rios, L. R. (2005). Measuring the relative efficiency of the operations of Mercosur container terminals. Dissertation, Rio Grande do Sul Federal University, Porto Alegre.

[Rodrimar] Terminal Rodrimar (2012). Operating facilities. http://www.rodrimar.com.br/ instalacoes-operacionais. Access: 9th July, 2015.

[Santos] Porto de Santos (2014). http://www. portodesantos.com.br/pressRelease.php?id Release=795. Access: 13th July, 2015.

[SEP/PR] Special Secretariat of Ports - Republic Presidency. (2012). http://www.portosdo brasil.gov.br/programas-eprojetos/pac/PAC. Access: 5th July, 2015.

Serebrisky, T.; Sarriera, J. M.; Suárez-Alemán, A.; Araya, G.; Briceno-Garmendía, C.; Schwartz, J. (2016). Exploring the drivers of port efficiency in Latin America and the Caribbean. Transport Policy. Vol. 45, pp. 31-45. 
Siqueira, G. A.; Leal Junior, I. C.; Cunha, L. C.; Guimarães, V. A.; Guabiroba, R. C. S. (2016). Analysis of technical efficiency and eco-efficiency in container terminals. International Journal of Shipping and Transport Logistics (in press).

Silva, S. D. (2010). The use of business games as an educational tool support. Rio de Janeiro Federal University: Rio de Janeiro.

[Tecondi] Terminal para Contêineres da Margem Direita do Porto de Santos (2012). http:// www.tecondi.com.br/ estrutura-e-tecnologia/tecnologia-e-equipamentos. Access: 12th July, 2015.

[Tecondi] Terminal para Contêineres da Margem Direita do Porto de Santos (2012). http: //www.apmterminals.com. br/estrutura. Access: 13th July, 2015.

[TESC] Terminal Portuário de Santa Catarina (2012). http://www.santosbrasil.com.br/pt-br/unidades-denegocios/tecon-imbituba/infraestrutura. Access: 13th July, 2015.

Tongzon, J.; Heng, W. (2005). Port privatization, efficiency and competitiveness: some empirical evidence from container ports (terminals). Transportation Research Part A. Vol. 39, pp. 405-424.

Tovar, A. C. A.; Ferreira, G. C. M. (2006). The Brazilian port infrastructure: the current model and prospects for sustained development. BNDES Magazine. Vol. 13, No. 25, pp. 209-230.

[UNCTAD] Conferência das Nações Unidas sobre Comércio e Desenvolvimento. (2014). http://www.unctad. org/en/ PublicationsLibrary/rmt2014_en.pdf. Access: 15th July, 2015.

Wang, T. F.; Song, D. W.; Culliname, K. (2002). The applicability of DEA to efficiency measurement of container ports. http://www.eclac.claac. Access: 29th July, 2015.

Wanke, P. F.; Barros, C. P. (2015). Public-private partnerships and scale efficiency in Brazilian ports: evidence from two-stage DEA analysis. Socio-Economic Planning Sciences. Vol. 51, pp. 13-22.

Wen, K. (2004). Grey Systems: Modeling and Prediction. Printed in USA by Yang's Scientific Press ISBN 0972121277.

Wilmsmeier, G.; Tovar, B.; Sanchez, R. J. (2013). The evolution of container terminal productivity and efficiency under changing economic environments. Research in Transportation Business \& Management. Vol. 8, pp. 50-66. 